\title{
太陽光発電を組合わせた光植物工場の経済効果
}

\author{
水島宜彦 \\ 静岡県浜北市中瀬 $7136-50$
}

\section{Economic Aspect of the Plant Factory Combined with Solar Power Generator}

\author{
Yoshihiko Mizushima \\ Nakaze 7136-50, Hamakita, Shizuoka
}

\begin{abstract}
Since the plant factory consumes a lot of electric power, an idea to combine with the solar power generator is proposed. By constructing the solar generator on top of the roof of the plant factory, the combined economic balance is estimated. It is shown that the combined system can be a good example of value-added power element. With the solar cell of an area, threefold of that of the plant factory, the system becomes a self-sustained power unit, which is proved economically feasible in the future.
\end{abstract}

\section{緒言}

太陽電池を用いて自然エネルギーを有効利用する問題 は今後の植物工場の重要な着眼点になるだろう。すなわ ち，完全制御型の光植物工場の欠点は多量の電力を消費 し, しかも太陽光を全く活用していないので, 心理的に も抵抗感がある.そこで, 工場の屋根は空いているので, これに太陽電池を載せたら全体としての電力収支はどう なるかという素朴な発想で, 組合わせた実験室を建設し た.これを稼動させて 2 年を経過したので，その結果を 以下に報告する。

組合わせの結果を分析検討することにより, 従来コス 卜高で採算に乗らないと言われてきた太陽光発電も光植 物工場の付加価値に助けられて, 商業ベースに乗りうる 可能性を指摘する. これは環境産業の将来にとって大切 な試みになるだろう。

太陽光発電と完全制御型光植物工場との組合わせを工 ネルギー経済の見地から考えてみる。マクロ経済からは, 光植物工場と太陽光発電 ${ }^{1,2)}$ とは本来は別のものであっ て, この組合わせには特別の関係は無い. しかし, 両者

1997 年 9 月 11 日受付

1997 年 12 月 1 日受理
を一体として見なしうるような場合，すなわち企業の環 境や立地条件などから経営収支が連結されているとき, 企業経営のようなミクロ経済の立場からは, この組合わ せに特別な意味を持たせることができる，本論文で考察 するのは, 太陽光発電の収支に完全制御型光植物工場の それを含めて論ずるような総合経営の立場であって, こ の時はこの組合わせの利点が発揮される.こういう商業 的な計算では単位エネルギーコストよりも, コスト絶対 值が重要なので, 以下その見地で論ずる.

また，その考察を延長すると, 消費者の見地からみた 自営菜園の価値も判断できる.これにより植物工場の普 及は底辺から促進されることになろうから，そのような 考察も付記した。

光植物工場では照明ランプの発熱があるので, ランプ 照射は気温の低い夜間に行うのが良く, ふつう昼夜逆転 して運転される。したがって太陽光発電とは半日のズレ があるので, 電気エネルギーを一時貯蔵する必要がある. これについては, 1992 年に余剒電力買取り制度が設け られ, 1993 年からは一般電力網と系統連携が認められ たので, 昼間の発電電力量をいったん電力網にプールし ておき, 夜間に引き出して使うことが可能になった。

ただし, こういう意味では, 植物工場の屋根に太陽電 池を置かなくても, 離れた場所に別久にあっても良い筈 
である．ここで，植物工場が自分の屋根に太陽電池を載 せる試みは, 完全制御型植物工場が太陽光を活用せずに 無駄にしているという批判に対処するためであって, 本 質的なものではないが，太陽光の有効活用という点では 当然の対策でもある。

この組合わせの特徵を考えてみる.

1. 両者は共にクリーンな環境保全型産業で, 資材の 消費や環境の污染が無い.

2. 太陽光はエネルギー密度としては薄いものである から, 太陽光発電は本来農村山林のような広い面積で始 めて経済的意味を持つ。一方農業では広い面積に日数を かけて光エネルギーを溜め込む.つまり両者の存立基盤 は類似している。

3. 光植物工場は電力を大量に消費する．電力のよう な良質のエネルギーを消費する以上は，発揮される付加 価値は大きくなくてはならない。一方太陽光発電では燃 料代(ランニングコスト)不要である。植物工場では電力 費(ランニングコスト)を改善すれば，組合わせによって， 全体の採算性が向上する可能性がある。その結果，あと で述べるように，エネルギー自立型システムを構築でき る.

4. 屋根に取り付けた太陽電池板は直射日光を遮断す るので，屋根は日陰状態に保たれる。したがって夏季の 熱侵入に関して屋根材の断熱負担を軽減し，または冷房 パワーを減らすことができる。(文献)ではこれを既に 考慮して計算した。）

\section{実験方法および装置と結果}

\section{1. モデル太陽光発電システム}

植物実験室の屋根に付設した太陽光発電システムは静 岡県浜北市にあり，年間平均日照時間は約 2,200 時間, 年平均全天日射量は $3.8 \mathrm{kWh} / \mathrm{m}^{2}$ 日と，国内ではやゃ 恵まれている地点である. 建物は南面して建てられ，そ の外観を写真 1 に示す。総建坪は $25 \mathrm{~m}^{2}$ であるが，うち 植物実験室部分は $15 \mathrm{~m}^{2}$ である。太陽電池はちょうどそ の真上に傾斜角 30 度で載せられた。ここに設備した多

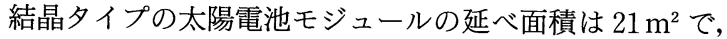
公称発電規格は $2.45 \mathrm{~kW}$ である。

この太陽光発電システムは新エネルギー財団からの住 宅用光発電システムモニター事業の補助金によって, 1995 年に建設された。太陽光発電部分の設備費用は, 機器が 473 万円, 工事諸経費を加えて 533 万円 (消費税 を含まず)であった(これに対する補助金は 227 万円).

以下では太陽電池で発電した電力をその付加価值で評

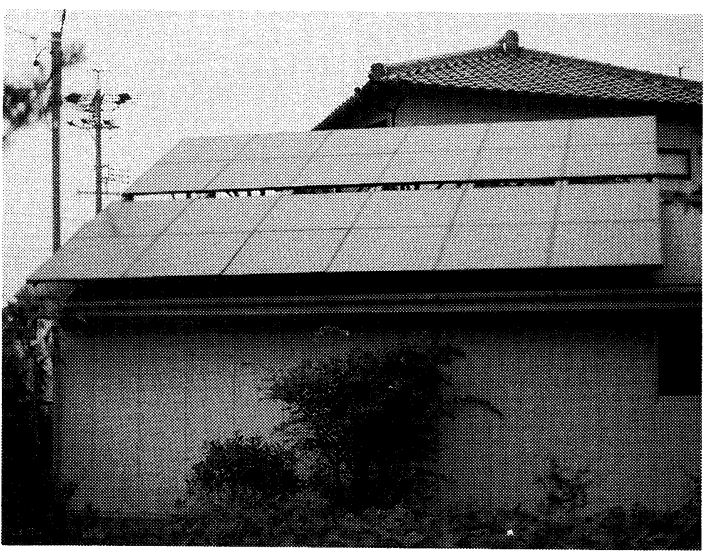

写真 1 モデル太陽光発電システム。太陽電池の 下部が光植物実験室.

Photo 1 Solar power generator on top of the small plant factory.

価する. 燃料コスト不要なので，設備投資と償却年数と から, 電力限界価格が決定される.

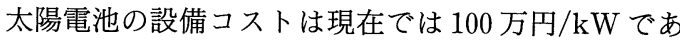
る. 発電所並みではなく, 通常の産業用の設備としての 8 年償却を仮定すれば，(実際には， 20 年以上保つと言 われているが，実績はない.)減価償却費用として 12.5 万円/年・ $\mathrm{kW}$ を見込む必要がある。もちろん，一般業 務用なので，補助金を考慮しない。一方年間発電量実績 は $3,069 \mathrm{kWh} /$ 年，あるいは $1,252 \mathrm{kWh} /$ 年・ $\mathrm{kW}$ であ る.したがって, 電力単価が 100 円 $/ \mathrm{kWh}$ 以上でない限 り，設備するほど損をする。しかし太陽光発電システム の価格は年々低下しており，2000 年ころには 53 万円/ $\mathrm{kW}$ といわれている2)ので，その場合の電力限界価格は 53 円 $/ \mathrm{kWh}$ となる．また，償却負担を軽減するために 発電設備と見做して 13 年償却と考えれば，限界価格は

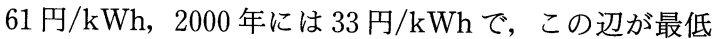
必要な付加価值である. それにしても現行の電力コスト より著しく高い．逆に言えば，利益を出すためには少な くとも 50 円 $/ \mathrm{kWh}$ 程度以上の付加価值が必要である, と言うことが本論文の出発点となる.

第 1 図に太陽光発電の実績を示す。毎日については当 然天候により極端な摇らぎがあるが，毎月にすると，そ れほどのバラツキは無く，平均的な傾向が現れる，季節 変動としては，むしろ極めて少ない。これは，日照時間 の長い夏日では朝夕の光入射方位角が北東から北西まで 回り込むので，固定された太陽電池板への垂直投影成分 では必ずしも有利ではないことと，温度が高いときには シリコン P N 接合からの出力電圧が下がる不利があり, 逆に日照時間の短い冬には方位角と温度の点で有利とな 


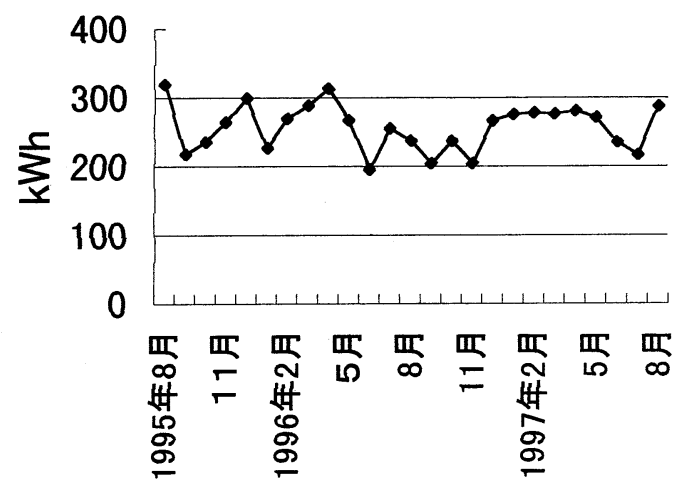

図 12 年間の太陽光発電成績. 毎月の積算発電 電力量の経過を示す.

Fig. 1 Trend of the generated electric power in $\mathrm{kWh}$ in each month.

るからである。天候の影響では 6 月と 9 月に雨季の影響 が現れやすい. 年間平均すると, フルパワー公称值での 運転時間にして，毎日 3.4 時間の実稼動に相当する。 こ れらのことは既に良く知られていて, 上記の数字はそれ とほぼ一致しているので，詳細は省略する.

本システムは住宅用補助金システムの関係で, 低圧電 力の価格 $(24$ 円 $/ \mathrm{kWh}$ )で電力会社に販売しているが, 将 来は高圧電力 $(13$ 円 $/ \mathrm{kWh})$ でも可能になるだろうから, それに換算して議論をすることもできる．もちろん電力 自給自足状態なら，価格はいくらであっても関係はない. 以下ではこれら電力価格の数字を使用せずに議論するの で, 電力コストの異なる外国においても論理の骨格は変 更を受けないことに注意したい.

\section{2. モデル光植物実験室}

実験室の内部構成はモデル植物工場)に準じたもので ある. 栽培植物は比較のために, サラダ菜とする。現実 にはその他の植物花卉をも多種栽培しており, 経済的に は花卉のほうが有利であるが，これらの経済評価は現時 点では困難である.そこで，モデル植物工場と同じ条件 でのサラダ菜について，その部分のデータを全体に換算 して述べる.

モデル植物工場と同じパネル密度では(1.0パネル/ $\left.\mathrm{m}^{2}\right)$ 生産率は 10,000 株/年となる筈だが4), 小さな部屋 なので, 有効面積率したがってパネル数の割合は不利と なっている. すなわち使用パネル数は 11 枚, うち出荷 栽培用に 10 枚を使用できる. パネル栽埴密度は同等な ので, 年間 7,000 株出荷可能である. さらに炭酸ガス濃 度を高めることにより，この約 2 倍は可能である ${ }^{5)}$ が, これは後で考える.

必要な照明電力は, 実績から $8,200 \mathrm{kWh} /$ 年の程度で
ある、これに追加される冷暖房電力については, 前の論 文 3)に述べた運転方法を使用している，すなわち，冬 季には暖房を僅か, ないしほとんど使用しない程度に全 体の熱環境を調整すると, その他の雑用電力を加えても, ほほ照明電力の $30 \%$ で斉んだ. 計 $10,660 \mathrm{kWh} /$ 年とな る. 消費電力量の数字がモデル工場の数字に比べてやや 低めに出ているのは, 前報告3)で種々述べた改善の効果 である，この消費電力は, 前記発電電力量の 3.4 倍に相 当する。

\section{考察}

太陽光発電システムから見た経済効果について考える. 太陽光発電による電力はそのコストが高く，未だ実用的 ではない. しかし，植物工場と組合わせることで，付加 価值をつけることができる、ここでは，1株あたり全積 算消費電力は $1.4 \mathrm{kWh} /$ 株と，ほほ標準的な值を確認で きているが，モデル植物工場の規模ならば，前記のよう に，パネル密度を高く取れるので, $1.0 \mathrm{kWh} /$ 株となる. さらに炭酸ガスによる増産効果を考えると, 約 0.7 $\mathrm{kWh} /$ 株となる5). したがって電力の付加価值は, 出荷 価格(卸値)を 70 円/株とすれば 50 ないし 100 円 $/ \mathrm{kWh}$ に相当するので, 前記の限界価格目標を達成できること は明らかである。

つまり, 電力の付加価值を平均 70 円 $/ \mathrm{kWh}$ 程度と見 積もると, 太陽光発電が植物工場と共同動作する限り, 8 年以下の償却期間で経営が成立する．これならば企業 的にも十分魅力的な数字である. あるいは逆に, 生産す る植物の出荷価格を下げて市場競争力を高められる.サ ラダ菜よりも花卉ならばもっと良い数字を期待できる.

もちろん，初めに述べたように，太陽光発電と光植物 工場とは独立のもので，組合わせの必然性はない。しか し,この組合わせにより, 光植物工場は太陽光発電の償 却負担を軽減することができるから, 環境保全型産業と して，現在でも既に農村に普及可能性を持っている.

設置必要面積について考えれば，上記のように，消費 電力は発電電力に比して 3.4 倍となる. したがって植物 工場と, その他に 2.4 倍の面積を太陽電池のために追加 すれば電力は見掛上自給できることになる.（上記経営

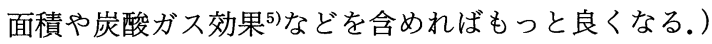
この程度の必要面積は植物工場によって集約化された土 地の余㮃で容易に賄うことができる，特に，山間地域で は斜面でも利用できるので，土地に関する問題はない. この比率が意外に小さいことは, 光植物工場の効率性を 示すものであって，その他の応用たとえば，宇宙空間， 
衛星内における植物栽培に応用する際にも明るい希望を もたらすものである.

次に, 消費者から見た分散型エネルギーシステムの経 済効果について述べる. 太陽光発電は, 薄いエネルギー 密度を集める発電であるので, 従来の発電所と違って, 集中して大容量を設備する意味が薄い。すなわち，農村 や家庭などに分散して，局部的なエネルギー経済に貢献 することが大切である，その意味で，植物〈工場〉との組 合わせは適当ではあるが，これを延長して，もっと小型 の家庭向きのものがあってもいい.

消費者の家庭で実行することを考えると，いくつかの 新しいメリットがある，現在では補助金を利用できる。 家庭では趣味と実益を兼ねるので，一般に人件費をカウ ントしない。 また家庭の設備は減価償却しない習慣があ る.（ローンは償却ではなく, 分割払いである.)このこ とを考えると, ランニングコストとして実際に出て行く 支出は電気代の他には肥料代, 炭酸ガス代, 水道代, ウ レタンなどの資材費だけである。この場合には株あたり のコストで比較しょう。このうち, 肥料代は株あたり 1 円以下で, 炭酸ガスは 3 円程度, 水道や資材は 1 円以下 で，ほとんど無視できる，残る電気代については，電力 会社から購入する場合，前記のように，10ないし 20 円/株であるが, これを小売り末端価格の 100 円/株程度 と比較するので, 割安感は著しい. したがって, 初期投 資と償却が無ければ，植物工場は生産農家よりも，まず 消費者家庭において受け入れられるべきものである。

更に本論文のように, 太陽電池で電力を自給すれば, これも只になるので, 諸雑費を含めて原価は 5 円/株以 下である。しかし現実には太陽電池の初期投資額が目立 ってしまい，さすがに家庭でも償却を考元ることになる ので，この点では消費者の意識に依存するところが大き く, 政策的援助が無い限り，簡単ではない. したがって, 現行の太陽電池価格なら, 太陽電池との組合わせは小型 の植物工場では非現実的である. 太陽光発電との組合わ せは，もう少し規模の大きい企業単位で検討されるべき 問題だろう。

\section{結 論}

光植物工場と太陽光発電とは，ミクロ経済的見地から は魅力のある良い組合わせであることを提案した。本実 験で説明した実験的建物は小さいので壁の割合が大きく 有効面積率や冷暖房効率の点で損をしているにも関わら ず，組合わせのメリットを指摘することができた。

光植物工場の建坪面積の 3 倍半の面積に太陽光発電設 備を設ければ, 見掛上ではこの産業はエネルギー自給が できる.ランニングコストだけで見ると, 極めて有望な ことを示した. 予定されるように, 太陽電池コストが低 下すれば，初期投資と減価償却とを含めても解決できる 可能性を示した.

特に, ローカル単位経済の代表としての消費者家庭の 立場からは，ほとんど只で，無農薬健康野菜が入手でき るなど魅力が多い. 住宅用太陽光発電にもこのような見 地を加味することが望ましい.

普及の鍵は太陽光発電システムの価格であるが, 光植 物工場との組合わせた形で評価することにより，環境を キーワードにして普及が促進されることを期待したい.

議論をいただいた長野県飯田市産業経済部長 松村茂 利氏に感謝する。

\section{引用文献}

1）浜川圭弘・桑野幸徳：アドバンストエレクトロニ クスシリーズ, 太陽エネルギー工学, 培風館 (1994)

2）日経エレクトロニクス：日経 BP 社，No.695： pp. 68-82 (1997)

3）水島宜彦：植物工場理論を基礎とした小規模植物 工場の最適設計, 植物工場学会誌, 9: 182192 (1997)

4）高辻正基：植物工場の理論, 日本植物工場学会, SHITA TECHNOLOGY, No. 1(1993)

5）水島宜彦：植物工場理論にもとづく炭酸ガス施肥 の経済効果, 植物工場学会誌，10(1)：5-9(1998) 